\title{
Effectiveness of biological control of Trichoderma harzianum on soybean leaf rust disease and the production in West Papua Lowland, Indonesia
}

\author{
EKO AGUS MARTANTO ${ }^{1}$, ADELIN E. TANATI ${ }^{1}$, SAMEN BAAN ${ }^{2}$, HERMAN R. TATA ${ }^{3}$, \\ AGUSTINUS MURDJOKO ${ }^{4, \bullet}$ \\ ${ }^{1}$ Laboratory of Plant Pests and Diseases, Faculty of Agriculture, Universitas Papua. Jl. Gunung Salju, Amban, Manokwari 98314, West Papua, Indonesia \\ ${ }^{2}$ Laboratory of Soil, Faculty of Agriculture, Universitas Papua. Jl. Gunung Salju, Amban, Manokwari 98314, West Papua, Indonesia \\ ${ }^{3}$ Center for the Assessment and Application of Technology. Jl. Brigjen Abraham O. Atururi, Manokwari 98135, West Papua, Indonesia \\ ${ }^{4}$ Faculty of Forestry, Universitas Papua. Jl. Gunung Salju, Amban, Manokwari 98314, West Papua, Indonesia. \\ "email: agustinus.murdjoko.papua@gmail.com
}

Manuscript received: 4 March 2020. Revision accepted: 12 April 2020.

\begin{abstract}
Martanto EA, Tanati AE, Baan S, Tata HR, Murdjoko A. 2020. Effectiveness of biological control of Trichoderma harzianum on soybean leaf rust disease and the production in West Papua Lowland, Indonesia. Biodiversitas 21: 1935-1939. This study aims to evaluate the application of Trichoderma harzianum in leaf rust disease on soybean and its production. The study was conducted for three months starting from May to July 2017, at Residential Unit 11th Sidey Subdistrict, Manokwari District, West Papua Province, Indonesia. This study was designed using Factorial Complete Randomized Design consisting of two treatment factors and repeated three times. There was no treatment of pathogen inoculation in the field. The tested varieties had a different response to plant height. Burangrang, Grobogan, Dena-1, Anjasmoro, and Detam-1 varieties were categorized as moderate resistant varieties. The Trichoderma harzianum application should be applied in the whole crops of soybean to control environmentally the leaf rust disease. Seeds weight per plot for Dena- 1 variety was higher compared to other varieties. The combination of Detam- 1 varieties with Trichoderma treatment 2 times resulted in increased production.
\end{abstract}

Keywords: Leaf rust, production, soybean, Trichoderma harzianum, West Papua

\section{INTRODUCTION}

Soybean is one of the important crops in Indonesia in which foods made of soybean contain high carbohydrates and isoflavones which is an anticancer (Astawan and Fabrinda 2009). Moreover, the high protein content at the level of $30.3-34.6 \%$ can be used as an alternative protein source (Yuwono et al. 2012). The development of foods and feeds industry with soybean as their raw materials is followed by the population growth causing the demand for soybean in Indonesia increases significantly. The development of foods and feeds industry with soybean as their raw materials is followed by the population growth causing the demand for soybean in Indonesia to increase significantly (Swastika et al. 2009).

Papua has abundant local food stock potency, particularly soybeans as a food source. Statistical data indicates that the soybean production for Manokwari reaches 1.1 ton/ha (Anonimous 2017). The total population of Papua is about 2.2 million with a population growth of $3.14 \%$ per year. The increasing population number has caused increased food demand. Therefore, soybean production increases, either by intensification or extensification should be constantly performed to reduce the dependence on imported soybeans (Sudjudi et al. 1989).

Sidey Makmur Village (Residential Unit $11^{\text {th }}$ ) is one of the development centers for soybean commodities in Manokwari with specific advantages that are not found in other regions in Indonesia, particularly the planting period
4 times in a year. This superiority is a potency that can increase yield productivity, but the obtained product is not as expected. One of the obstacles in increasing soybean productivity is pests and diseases attack. The important disease of soybean plants is leaf rust caused by Phakopsora pachyrhizi. Leaf rust disease, an important disease in soybean, occurs during summer (Semangun, 2008: Sumartini 2010: Soesanto 2015). Production loss due to leaf rust disease could reach $40-90 \%$ in Indonesia (Sudjono et al. 1985). Most of the planted varieties in Sidey Subdistrict are Anjasmoro variety. According to a description from Baliktabi Malang Indonesia, Anjasmoro variety resistance to rust is moderate. The planting of Anjasmoro variety continually will produce a new pathogenic race that can break the resistance of the variety. Therefore, an alternative variety is needed.

Biological control of diseased soybean plants can be done by utilizing microbes that are antagonistic to pathogenic fungi (Agrios 1996). Plant diseases control using biological agents can reduce chemical pesticide use. One of the antagonistic biological agents and can control the disease is Trichoderma harzianum. T. harzianum has ability as biological control with a wide spectrum in various crop plants. Several studies indicated that the antagonistic agent can reduce the plant diseases development from various pathogen attacks such as Elsinoe batatas in sweet potatoes (Martanto et al. 2015), Verticillium sp. in Strawberries (Suryawan et al. 2017), and Fusarium oxysporum in tomatoes (Fitrianingsih et al. 
2019). Trichoderma also has ability as parasite and antibiotic because it produces enzymes that actively degrading pathogenic cells, causing the lysis of pathogenic fungus cells and release tritoxin that can kill pathogenic fungi (Octriana 2011). The chitinase enzyme produced by Trichoderma sp. more effective than chitinases produced by other organisms in inhibiting various pathogenic fungi (Umrah et al. 2009).

The implementation of biological control can be applied as a single method or combined with other control techniques simultaneously. The use of Trichoderma harzianum and the use of several resistant soybean varieties is the combined control expected to control the attack of $P$. pachyrhizi. So far, the effectiveness of spraying and the use of several soybean varieties in controlling leaf rust is not known. Thus, the study on soybean to know the effect of $T$. harzianum on leaf rust control in soybean plant and its production is relevant to conduct. This study aims to evaluate the utilization of $T$. harzianum in controlling the leaf rust disease on soybean and its production.

\section{MATERIALS AND METHODS}

\section{Study area}

This study was conducted in Laboratory of Plant Pests and Diseases, Faculty of Agriculture, University of Papua, Manokwari, Indonesia (latitude $00^{\circ} 70^{\prime} 76^{\prime}$ 'S, longitude $134^{\circ} 06^{\text {' }} 79^{\text {" }} \mathrm{E}$, latitude 126 ), and in Residential Unit $11^{\text {th }}$ of Sidey Subdistrict, Manokwari District, Indonesia (latitude $00^{\circ} 45^{\prime} 34^{\prime \prime} \mathrm{S}$, longitude $133^{\circ} 32^{\prime} 39^{\prime \prime} \mathrm{E}$, altitude 39 ).

\section{Experimental design and protocol}

This study used factorial Complete Random Design consisting of antagonist factor and variety, repeated three times. The antagonist factor consisted of T0 (without application of Trichoderma harzianum), T1 (application of Trichoderma harzianum 1 time) and T2 (application of Trichoderma harzianum 2 times). Whereas the variety factor consisted of V1 (Burangrang variety), V2 (Grobogan variety), V3 (Dena-1 variety), V4 (Anjasmoro variety), and V5 (Detam-1 variety).

Antagonist and its application. Trichoderma harzianum that isolated from rhizosphere in this are were multiplied in the rice husk medium. Isolates were applied by spraying on to the leaf surfaces at 4 weeks after planting. The density of Trichoderma harzianum spores was $10^{7}$ spores. $\mathrm{mL}^{-1}$ water.

Tabel 1. Plant response to leaf rust disease using the formula by Yuspamella et al. (2013)

\begin{tabular}{ll}
\hline \multicolumn{1}{c}{ Description } & \multicolumn{1}{c}{ Response scale } \\
\hline No rust & Very resistant \\
$1-10 \%$ of leaf infected & Resistant \\
$11-40 \%$ of leaf infected & moderate resistant \\
$41-65 \%$ of leaf infected & Susceptible \\
$66-100 \%$ of leaf infected & Very Susceptible \\
\hline
\end{tabular}

The intensity of leaf rust disease. Disease intensity was calculated according to the percentage of occurring disease symptoms. Disease intensity was observed 3 weeks after planting (WAP), repeated 4 times with 2 weeks interval between observation. The intensity of leaf rust was calculated with the following formula $I P=$ $\frac{\sum n_{i} \times v_{i}}{N \times V} \times 100 \%$ where, IP $=$ Disease Intensity, ni $=$ Number of plant from attack category, vi = Scale value of each attack category, $\mathrm{N}=$ Number of observed plants, and $\mathrm{V}=$ Highest scale value. Attack value category referred to Safitri et al. (2015) with the following category: $0=$ No attack, $1=0-25 \%$ of leaf surface area attacked, $2=26-50 \%$ of leaf surface area attacked, $3=51-75 \%$ of leaf surface area attacked, and $4=76-100 \%$ of leaf surface area attacked

Antagonist effectiveness. Antagonist agent effectiveness was calculated according to Abbott (Ditjen PSP 2004). The formula is $\mathrm{El}=\left[\frac{\mathrm{Ca}-\mathrm{Ta}}{\mathrm{Ca}}\right] \times 100 \%$ where, $\mathrm{El}=$ Efficacy of Antagonist Agent $(\%), \mathrm{Ca}=$ Disease intensity in control/without treatment, $\mathrm{Ta}=$ Disease intensity in treatment/after application. The effectiveness value of antagonist fungus was categorized as follow: $\mathrm{E}>69 \%$ very good, $\mathrm{E}=50-69 \%$ good, $\mathrm{E}=30-49 \%$ less good, and $\mathrm{E}<$ $30 \%$ not good.

Plant height $(\mathrm{cm})$. Plant height was measured starting from stem base to highest leaf. Plant height was measured at the age of 3 weeks after planting, repeated 4 times with 2 weeks interval between measurement.

Weight of 100 seeds $(\mathrm{g}) .100$ seeds were collected randomly from the plant sample and weighted.

Seed weight per plot $(\mathrm{g} / \mathrm{plot})$. The beans harvest in each trial square was weighted.

\section{Data analysis}

The data were analyzed using Analysis of Variance when the real effect of treatments then continued with DMRT (Duncan Multiple Range Test) on the level of $95 \%$ (Gomez and Gomez 2010).

\section{RESULTS AND DISCUSSION}

\section{Disease intensity}

At 5 WAP, leaf rust symptoms had been observed in all studied soybean varieties. Symptoms were observed on leaves, initially manifested as gray-brown small patches and then changed into deep brown or brown patches. At 9 WAP, the intensity of rust was highest in Anjasmoro variety $(38.45 \%)$, and the lowest in Detam-1 variety $(31.04 \%)$ (Table 1). The intensity of rust disease with the treatment of 2-time T. harzianum was $31.35 \%$ and lower compared to treatment with 1-time T. harzianum (33.12\%) and control (36.38\%). The effectiveness of antagonist fungi with two applications was $13.83 \%$, better than those with one application $(8.96 \%$ ) (Table 1). Disease intensity with combined treatment at 9 WAP was lowest in V2T2 $(27.45 \%)$ and highest in V1T0 (42.34\%) (Table 2). 
Table1. Observed disease intensity in soybean varieties and $T$. harzianum treatments. Values followed by a similar letter in the same column are not significantly different according to Duncan Multiple Range Test at 5\% level while the values not followed by letter are not significantly different. WAP stands for weeks after planting.

\begin{tabular}{lcccc}
\hline \multirow{2}{*}{ Treatment } & \multicolumn{5}{c}{ Disease intensity at (\%) } \\
& 3 WAP & 5WAP & 7 WAP & 9 WAP \\
\hline V1: Burangrang & 0.00 & $8.65 \mathrm{abc}$ & $14.76 \mathrm{ab}$ & 34.08 \\
V2: Grobogan & 0.00 & $11.46 \mathrm{a}$ & $15.83 \mathrm{ab}$ & 32.28 \\
V3: Detam-1 & 0.00 & $8.25 \mathrm{~b} \mathrm{c}$ & $12.44 \mathrm{~b}$ & 32.23 \\
V4: Anjasmoro & 0.00 & $10.51 \mathrm{ab}$ & $17.18 \mathrm{a}$ & 38.45 \\
V5: Detam 1 & 0.00 & $6.34 \mathrm{c}$ & $12.73 \mathrm{~b}$ & 31.04 \\
T0: No application & 000 & 9.09 & 14.92 & 36.38 \\
T1: 1 application & 0.00 & 7.79 & 13.92 & 33.12 \\
T2: 2 applications & 0.00 & 10.24 & 15.21 & 31.35 \\
& & & & \\
T. harzianum effectiveness $(\%)$ & & & \\
T1: 1 application & 0.00 & 14.30 & 6.70 & 8.96 \\
T2: 2 application & 0.00 & -12.65 & -0.02 & 13.83 \\
\hline
\end{tabular}

Table 3. Plant height in soybean variety and observed $T$. harzianum treatments. Values followed by a similar letter in the same column are not significantly different according to Duncan Multiple Range Test at 5\% level while the values not followed by letter are not significantly different. WAP stands for weeks after planting.

\begin{tabular}{lllll}
\hline \multicolumn{1}{c}{ Treatment } & \multicolumn{4}{c}{ Plant height } \\
& 3 WAP & 5 WAP & 7 WAP & 9 WAP \\
\hline V1: Burangrang & $23.73 \mathrm{~b}$ & $49.09 \mathrm{a}$ & $69.36 \mathrm{a}$ & $69.38 \mathrm{~b}$ \\
V2: Grobogan & $25.60 \mathrm{a}$ & $44.98 \mathrm{bc}$ & $49.62 \mathrm{c}$ & $49.09 \mathrm{~d}$ \\
V3: Detam-1 & $23.36 \mathrm{~b}$ & $48.53 \mathrm{ab}$ & $71.18 \mathrm{a}$ & $75.89 \mathrm{a}$ \\
V4: Anjasmoro & $24.04 \mathrm{~b}$ & $46.71 \mathrm{abc}$ & $59.78 \mathrm{~b}$ & $66.16 \mathrm{~b} \mathrm{c}$ \\
V5: Detam 1 & $21.31 \mathrm{c}$ & $43.16 \mathrm{c}$ & $58.76 \mathrm{~b}$ & $63.29 \mathrm{c}$ \\
T0: No application & $24.33 \mathrm{a}$ & $46.83 \mathrm{ab}$ & $63.11 \mathrm{a}$ & $61.61 \mathrm{~b}$ \\
T1: 1 application & $24.48 \mathrm{a}$ & $48.27 \mathrm{a}$ & $63.13 \mathrm{a}$ & $64.95 \mathrm{a}$ \\
T2: 2 applications & $22.01 \mathrm{~b}$ & $44.39 \mathrm{~b}$ & $58.97 \mathrm{~b}$ & $67.72 \mathrm{a}$ \\
\hline
\end{tabular}

Observations at 5 WAP began to detect leaf rust symptoms in all tested varieties. The delayed occurring symptoms were caused by the fact that during study no inoculation of leaf rust pathogen was performed. The study location was a region with continuous soybean planting making the inoculum sources are always available. Observation at 9 WAP, Anjasmoro variety was the most vulnerable variety with the highest disease intensity, whereas Detam- 1 had the lowest disease intensity. The high disease intensity can contribute to decreased production. This is in accordance with Djauhari (2008), that rust disease attack can reduce production by $60-80 \%$. According to the occurring disease intensity extent, all tested varieties were categorized as moderately resistant to rust disease. The disease intensity difference in each variety was related to different resistance of each variety. The developing leaves in all varieties causing the microclimate around the plant supports the development of the pathogen.
Table 2. The effect of the combination of variety and $T$. harzianum on observed parameters.

\begin{tabular}{ccccc}
\hline Treatment & $\begin{array}{c}\text { Disease } \\
\text { intensity } \\
\text { (\%) }\end{array}$ & $\begin{array}{c}\text { Plant height } \\
\text { 9 WAP }\end{array}$ & $\begin{array}{c}\text { Weight/ } \\
\text { 100 seeds } \\
\text { (g) }\end{array}$ & $\begin{array}{c}\text { Seed } \\
\text { weight per } \\
\text { square (g) }\end{array}$ \\
\hline W WAP & & 18.96 & 516.66 \\
V1T0 & 42.34 & $67 \mathrm{~cd}$ & 18.96 & 523.33 \\
V1T1 & 27.81 & $70.47 \mathrm{bc}$ & 19.00 & 543.33 \\
V1T2 & 32.09 & $70.67 \mathrm{bc}$ & 18.5 & 443.33 \\
V2T0 & 36.09 & $46.93 \mathrm{~g}$ & 15.5 & 416.66 \\
V2T1 & 33.29 & $46.53 \mathrm{~g}$ & 18.87 & 53.86 \\
V2T2 & 27.45 & $53.8 \mathrm{f}$ & 19.87 & 506.66 \\
V3T0 & 35.77 & $75.27 \mathrm{ab}$ & 13.1 & 856.66 \\
V3T1 & 3249 & $73.27 \mathrm{abc}$ & 12.9 & 893.33 \\
V3T2 & 28.42 & $79.13 \mathrm{a}$ & 13.2 & 1086.66 \\
V4T0 & 39.42 & $59.33 \mathrm{ef}$ & 16.7 & 393.33 \\
V4T1 & 40.23 & $66.2 \mathrm{cde}$ & 17.93 & 370 \\
V4T2 & 35.69 & $72.93 \mathrm{abc}$ & 18.56 & 520 \\
V5T0 & 28.26 & $59.53 \mathrm{ef}$ & 16.83 & 483.33 \\
V5T1 & 31.78 & $68.27 \mathrm{bcd}$ & 20 & 533.33 \\
V5T2 & 33.08 & $62.07 \mathrm{de}$ & 18.93 & 620 \\
\hline
\end{tabular}

Note: Values followed by a similar letter in the same column are not significantly different according to Duncan Multiple Range Test at 5\% level while the values not followed by letter are not significantly different. WAP stands for weeks after planting. The symbols of treatments are V1: Burangrang, V2: Grobogan, V3: Detam-1, V4: Anjasmoro, V5: Detam 1, T0: No application, T1: 1 application and T2: 2 applications

Zadoks and Schein (1979) suggested that mico climate is an important requirement for the infection cycle, starting from the attachment of spores to the spreading of spores. Disease intensity in the 2-time $T$. harzianum application was lower compared to the intensity in control. Taufik (2010) suggested that Trichoderma sp. can compete for space and food and capable of stressing pathogen development in soil and plant tissues and induce resistance and inactivation of pathogenic enzymes. Papavizas (1985) suggested that Trichoderma sp. produces Trichoderin which is a toxin to pathogens. The toxin reduces the growth and reproduction of the pathogens (Rivera-Méndez et al. 2020; Alamri et al. 2019; Ghorbanpour et al. 2018). Ditjen PSP (2004) added that Trichoderma sp. can suppress the growth of pathogens by entwining the pathogenic hyphae, releasing enzymes $\beta-(1-3)$ (Sumida et al. 2018) and chitinase that can penetrate the host cell wall. According to Purwantisari and Hastuti (2009), Trichoderma sp. can colonize the rhizosphere quickly and protecting roots from pathogens attack (Ojaghian et al. 2019; Mercl et al. 2020; Moya et al. 2020).

\section{Disease intensity}

At 9 WAP, the plant height of Dena-1 variety (75.89 $\mathrm{cm})$ was higher compared other four varieties. Plant height in the treatment of $2 T$. harzianum applications $(67.72 \mathrm{~cm})$ was higher than the treatment of $1 T$. harzianum application and control (Table 3). The best combination was obtained with Dena-1 variety treated with $2 T$. harzianum applications (V3T2) with a height of $79.13 \mathrm{~cm}$ (Table 2). 
Table 4. Weight per 100 seeds, and seed weight per square of tested soybean variety and T. harzianum application. Values followed by a similar letter in the same column are not significantly different according to Duncan Multiple Range Test at $5 \%$ level while the values not followed by letter are not significantly different.

\begin{tabular}{lll}
\hline \multicolumn{1}{c}{ Treatment } & $\begin{array}{c}\text { Weight per 100 } \\
\text { seeds }(\mathbf{g})\end{array}$ & $\begin{array}{c}\text { Seed weight } \\
\text { per plot }(\mathbf{g})\end{array}$ \\
\hline V1: Burangrang & $18.82 \mathrm{a}$ & $527.78 \mathrm{~b}$ \\
V2: Grobogan & $18.08 \mathrm{a}$ & $455.55 \mathrm{~b}$ \\
V3: Detam-1 & $13.07 \mathrm{~b}$ & $945.56 \mathrm{a}$ \\
V4: Anjasmoro & $17.73 \mathrm{a}$ & $427.78 \mathrm{~b}$ \\
V5: Detam 1 & $18.59 \mathrm{~b}$ & $545.56 \mathrm{~b}$ \\
T0 (No application) & $16.22 \mathrm{~b}$ & 538.67 \\
T1 (1 application) & $17.74 \mathrm{a}$ & 547.33 \\
T2 (2 applications) & $17.82 \mathrm{a}$ & 655.33 \\
\hline
\end{tabular}

Plant height is an important variable in observing plant growth because it relates to the number of leaves developed. Study findings indicated that Detam- 1 had the highest plant height with the highest production. Malik et al. (2013) suggested that plant height is an important character because it positively correlates to beans yield. Plant height difference occurs due to genetics carried by each of the varieties. Sopialena (2015) suggested that plant variety reaches the highest growth limit according to its genetic traits. The application of antagonists influences plant height. The administration of $T$. harzianum causes the plant height is higher compared to those without antagonists. In addition to its ability in suppressing pathogen growth, T. harzianum is also a phosphate dissolving microorganism that can be used by plants, so the growth of plant height occurs in good progress as it has growth-promoting effect. This is in accordance with Setiadi (1989) that the presence of T. harzianum in the soil is in synergy with the phosphate dissolving bacteria (Mercl et al. 2020; Ojaghian et al. 2019).

\section{Weight per 100 seeds, and seed weight per square}

There was a significant difference in weight per 100 seeds, and seed weight per square among the tested soybean varieties. The highest seed weight per square was found in Dena-1 variety (945.56 g/square) and the treatment of $2 T$. harzianum applications $(655.33 \mathrm{~g})$ (Table 4). Soybean seeds weight per square was highest in the combination of V3T2 (1086,86 g) (Table 2).

Two applications of $T$. harzianum caused the pathogens were difficult in attacking soybean plants, so its production is higher. T. harzianum is capable of decomposing organic materials from rice husk, and in the decomposition process, the antagonist alters elements in a dissolved form so they can be absorbed by plants (Coelho et al. 2020). According to Suryawan et al. (2017) Potassium element in rice husk that can increase plant resistance to disease and antagonist able to inhibit disease progression. Broto et al. (1994) suggested that rice husks used as treatment medium provide abundant inorganic and organic components. The available carbohydrate and cellulose are utilized by $T$. harzianum sp. as an energy source and carbon source in the decomposition process (Jin and Custis 2011). Pod weight per 100 seeds of Detam-1 variety was the lowest, but its seeds weight per plot was the highest. This was because the seeds produced by Dena- 1 variety were higher than other varieties.

\section{The application of Trichoderma harzianum}

The tested varieties had different responses to parameters of plant height. Burangrang, Grobogan, Dena1, Anjasmoro, and Detam-1 varieties were categorized as moderate resistant. The $T$. harzianum application should be applied regularly in the whole crop of soybean to regulate environmentally leaf rust disease. Seeds weight per plot of Dena- 1 variety was higher compared to other varieties. The combination of Detam-1 varieties with $T$. harzianum treatment 2 times resulted in the best production. Therefore, the use of $T$. harzianum indicated that this method is environmentally friendly (Sumida et al. 2018; Khalili et al. 2016) since the method is harmless to biodiversity in soybean crops as well as the environmental condition surrounding the crop. The use of biological control such as T. harzianum to prevent the disease would also provide the organic nutrients in the soil since the biological controls can improve healthy soil biology by supporting nutrient uptake and root growth (Sumida et al. 2018) as the roots are imperative for supporting the metabolism (Hanudin et al. 2014). Therefore, this method supports biodiversity since it allows the organisms to live such as Phakopsora pachyrhizi itself. Even though P. pachyrhizi is pathogen but still part of biodiversity. Furthermore, this method could provide the benefit economically for the owner and ecologically for promoting the biodiversity along with its environment.

\section{ACKNOWLEDGEMENTS}

The authors thank the government through DP2M Ditjen DIKTI for financial support in 2017 to this study. We are greatly grateful to anonymous reviewers for improving this research.

\section{REFERENCES}

Agrios GN. 1996. Science of Plant Disease. Ed. 3. Gajah Mada University Press. Yogyakarta. [Indonesian]

Alamri, Saad AM, Hashem M, Mostafa YS, Nafady NA, Kamal AM, Abo-Elyousr. 2019. Biological Control of Root Rot in Lettuce Caused by Exserohilum Rostratum and Fusarium Oxysporum via Induction of the Defense Mechanism. Biological Control 128: 76-84. DOI: 10.1016/j.biocontrol.2018.09.014.

Astawan M, Fabrinda AE. 2009. Soybean Isoflavones as anticancer. Pangan 55 (18): $42-50$ [Indonesian]

Broto S, Sutater T, Bahor FA, Krisnawati, Sulihati S. 1994. Results of Horticultural Research. Pelita V. Horticulture Research and Development Center, Jakarta

Coelho, Luísa, Mário Reis, Carlos Guerrero, Lídia Dionísio. 2020. Use of Organic Composts to Suppress Bentgrass Diseases in Agrostis Stolonifera. Biological Control 141 (December 2019): 104154. DOI: 10.1016/j.biocontrol.2019.104154.

Ditjen PSP (Directorate General of Agricultural Infrastructure). 2004. Standard of Insecticide Efficacy Testing. Directorate General of Agricultural Facility Development. Directorate of Fertilizer and Pesticide. Agriculture Department, Jakarta. [Indonesian] 
Djauhari S. 2008. Character of anatomy soybean leaf affects leaf rust intensity. Agrivita 30: 388-392.

Fitrianingsih A, Martanto EA, Abbas B. 2019. The effectiveness of fung Gliocladium fimbriatum and Trichoderma viride to control fusarium wilt disease of tomatoes (Lycopersicum esculentum). Indian J Agric Res 53 (1): 57-61.

Ghorbanpour, Akram, Salimi A, Ghanbary MAT, Pirdashti H, Dehestani A. 2018. The effect of Trichoderma harzianum in mitigating lowtemperature stress in tomato (Solanum lycopersicum L.) plants. Scientia Horticulturae 230: 134-41. DOI 10.1016/j.scienta.2017.11.028.

Gomez KA, Gomez AA. 2010. Statistical Procedures for Research Agriculture. University of Indonesia Press, Jakarta. [Indonesian]

Hanudin E, Sukmawati, Radjagukguk B, Yuwono NW. 2014. The effect of humic acid and silicic acid on P adsorption by amorphous minerals. Procedia Environ Sci 20: 402-9. DOI: 10.1016/j.proenv.2014.03.051.

Jin X, Custis D. 2011. Microencapsulating aerial conidia of Trichoderma harzianum through spray drying at elevated temperatures. Biol Contr 56 (2): 202-8. DOI: 10.1016/j.biocontrol.2010.11.008

Khalili E, Javed MA, Huyop F, Rayatpanah S, Jamshidi S, Wahab RA. 2016. Evaluation of Trichoderma isolates as potential biological control agent against soybean charcoal rot disease caused by Macrophomina phaseolina. Biotechnol Biotechnol Equip 30 (3): 47988. DOI: 10.1080/13102818.2016.1147334.

Malik MFA, Ashraf M, Qureshi AS, Khan MR. 2013. Investigation and comparison of some morphological traits of the soybean populations using cluster analysis. Pak J Bot 43: 1249-1255.

Martanto EA, Tanati A, Baan S, Saleh DMM, Melinda. 2015. Utilization of Trichoderma $\mathrm{sp}$ for controlling scab disease of sweet potato. Kongress IX and PFI National Seminar 11-13 November 2015 Jakarta. [Indonesian]

Mercl F, García-Sánchez M, Kulhánek M, Košnář Z, Száková J, Tlustoš P. 2020. Improved phosphorus fertilisation efficiency of wood ash by fungal strains Penicillium sp. PK112 and Trichoderma harzianum OMG08 on acidic soil. Appl Soil Ecol 147. DOI 10.1016/j.apsoil.2019.09.010.

Moya, Paulina, Barrera V, Cipollone J, Bedoya C, Kohan L, Toledo A, Sisterna M. 2020. New isolates of Trichoderma spp. as biocontrol and plant growth-promoting agents in the pathosystem Pyrenophora teres-barley in Argentina. Biol Contr 141: 104152. DOI 10.1016/j.biocontrol.2019.104152.

Octriana L. 2011. Potential of biological agents inhibiting the growth of Phytium sp. in vitro. Plasma Nutfah 17 (2): 138-142.

Ojaghian, Seyedmohammadreza, Wang L, Xie GL, Zhang JZ. 2019 Effect of volatiles produced by Trichoderma spp. on expression of glutathione transferase genes in Sclerotinia sclerotiorum. Biol Contr 136: 103999. DOI: 10.1016/j.biocontrol.2019.103999.

Papavizas GC. 1985. Trichoderma sp. and Gliocladium sp. biology, biology and potential for biocontrol. Ann Rev Phytopathol 23: 23-54.

Purwantisari S, Hastuti RB. 2009. Isolation and identification of indigenous rhizosphere mushroom potato from organic farming farm in Pakis Village. Bioma 11 (2): 45-53

Rivera-Méndez, William, Obregón M, María E. Morán-Diez, Hermosa R, Monte E. 2020. Trichoderma asperellum biocontrol activity and induction of systemic defenses against sclerotium cepivorum in onion plants under tropical climate conditions. Biol Contr 141: 104145. DOI: 10.1016/j.biocontrol.2019.104145.

Safitri N, Sastrahidayat IR, Muhibuddin A. 2015. Utilization of Vegetable Extracts Basil leaf, Sirih leaf and Bay Leaf In the Prevention of Rust Disease Attack on Soybean. Jurnal Hama dan Penyakit Tanaman 3 (3): 52-62. [Indonesian]

Semangun H. 2008. Disease of Food Plant in Indonesia. Gajah Mada University Press, Yogyakarta. [Indonesian]

Setiadi Y. 1989. Utilization of Microorganisms in Forestry. Center of Inter University-Biotechnology. IPB Bogor, Bogor.

Soesanto L. 2015. Compendium of Soybean Diseases. Bumi Aksara, Jakarta. [Indonesian]

Sopialena. 2015. Resistance of some tomato varieties against fusarium oxysporum disease with Trichoderma sp. J Agrifor 14 (1): 130-140

Sudjono MS, Amir M, Roechan M. 1985. Rust disease and its prevention. In: Somaatmadja, S., M. Ismunadji, and Yuswadi (Ed). Soybean. Center for Food Crops Research, Bogor.

Sudjudi R, Suwardjo AA, Abujamin S. 1989. The Use of Crop Residue Mulch to Minimize Tillage Frequency. Pemb. Pen. Tanah dan Pupuk, Jakarta.

Sumartini. 2010. Rust Disease in Soybean and Its Environmentally Friendly Control. J Agric Re Dev 29 (3): 107-112.

Sumida, Ciro H, Daniel JFS, Araujod APCS, Peitl DC, Abreu LM, Dekker RFH, Canteri MG. 2018. Trichoderma asperelloides antagonism to nine sclerotinia sclerotiorum strains and biological control of white mold disease in soybean plants. Biocontr Sci Technol 28 (2): 142-56. DOI: 10.1080/09583157.2018.1430743.

Sumida, Ciro H, Daniel JFS, Araujod APCS, Peitl DC, Abreu LM, Dekker RFH, Canteri MG. 2018. Trichoderma asperelloides antagonism to nine sclerotinia sclerotiorum strains and biological control of white mold disease in soybean plants. Biocontr Sci Technol 28 (2): 142-56. DOI: 10.1080/09583157.2018.1430743.

Suryawan L, Wirya GNAS, Sudiarta IP. 2017. The usage of Trichoderma sp. that added into a variety of compost for the control of wilt disease in strawberries (Fragaria sp.). E-journal Trop Agroecotechnol 6 (4): 481-490.

Swastika DKS, Nuryanti S, Sawit MH. 2007. Indonesia's position in international trade of soybean. In: Sumarno, Suyamto, Widjono A, Hermanto, Kasim H (eds.). Soybean. Center for Food Crops Research, Bogor.

Taufik M. 2010. Effectiveness of agent antagonist Trichoderma sp. on various growing media against tomato plant disease. Proceedings of Scientific Seminar and Annual Meeting of PEI PFI XIX Regional Commissariat of South Sulawesi. November 5, 2008

Anggreani UT, Esyanti RR, Aryantha PNI. 2009. Antagonists and Effectiveness Trichoderma sp in Suppressing Development of Phytophthora palmivora On Cocoa Fruit. Jurnal Agroland 16 (1): 916.

Yuspamella CN, Serafinah I, Prayoga Y. 2013. Response Several Sorghum (Sorghum bicolor (L.) Moench) against Leaf Rust Disease (Puccinia sorghi Schw.). Jurnal Biotropika 1 (1): 33-37 [Indonesian]

Yuwono SS, Hayati KK. Wulan SN. 2012. Physical, chemical, and protein fractions of $7 \mathrm{~S}$ and $11 \mathrm{~S}$ ten varieties of Indonesian soybean production. Jurnal Teknologi Pertanian 4 (1): 84-90.

Zadoks JC, Schein RD. 1979. Epidemiology and Plant Disease Management. Oxford Univ. Press, New York. 